\title{
Assessment of habitat and water quality of the Portuguese Febros River and one of its tributaries
}

\author{
Ana Bio ${ }^{1, *}$, Natividade Vieira ${ }^{1,2}$, Maria João Costa $^{2}$, Alexandre Valente $^{2,3}$ \\ ${ }^{1}$ CIMAR/CIIMAR-Centro Interdisciplinar de Investigação Marinha e Ambiental, Universidade do Porto, Rua \\ dos Bragas 289, 4050-125 Porto, Portugal. \\ ${ }^{2}$ Departamento de Biologia, Faculdade de Ciências, Universidade do Porto, Rua Campo Alegre s/n, 4169-007, \\ Porto, Portugal. \\ ${ }^{3}$ Unidade de Investigação em Eco-Etologia, I. \& D.-Fundação para a Ciência e Tecnologia-N. o 331/94. \\ * Corresponding author: anabio@ ciimar.up.pt
}

Received: 6/9/10

Accepted: 25/2/11

\begin{abstract}
Assessment of habitat and water quality of the Portuguese Febros River and one of its tributaries

A physical, chemical and biological characterisation of river systems is needed to evaluate their ecological quality and establish restoration programs. Aquatic benthic macroinvertebrates have proven to be among the most reliable and cost-effective assessment tools for water and habitat quality in streams throughout the world. During one year of seasonal surveys, the state of the Febros River and one of its tributaries, Jaca Creek, were evaluated in terms of habitat, physical, chemical and biological water quality, using benthic macroinvertebrates as ecological indicators. These watercourses suffer pollution from agriculture, industry and urban areas. Both watercourses were moderately to severely degraded, showing spatial and temporal variability in macroinvertebrate communities and water quality. The overall poor river conditions were particularly bad in the upper part of Jaca Creek, which is affected by industry. This upriver site showed higher temperatures, conductivity and dissolved solids than all other sites studied. The best conditions were found in the Gaia Biological Park area, where the habitat quality was evaluated to be high and biotic indices indicated excellent and good water quality in the spring and summer, respectively. However, even this site had biological indicator scores denoting severe degradation in autumn and winter. Macroinvertebrate diversity was low, with populations dominated by pollution-tolerant taxa like Chironomids, particularly in the summer and autumn samples. Abundances were mostly higher in the spring and lower in winter. Percentages of Ephemeroptera and Trichoptera (EPT) were low (totalling $31 \%$ on average), and Plecoptera was completely absent in the samples. The EPT percentage and the percentage of Chironomidae were related to temperature and Biochemical Oxygen Demand (BOD). In comparison to earlier studies, the Febros River improved in both habitat and biological quality. The present study should help to identify specific measures necessary to restore habitat and water quality to reference conditions.
\end{abstract}

Key words: Biotic indices, ecological indicators, benthic macroinvertebrates, water quality.

\section{RESUMEN}

\section{Evaluación del hábitat y la calidad de agua del río portugués Febros y uno de sus tributarios}

Para evaluar la calidad ecológica de un río y establecer programas de recuperación es necesaria una caracterización física, química y biologica de los sistemas fluviales. Los macroinvertebrados acuáticos bentónicos se encuentran entre las herramientas más fiables y efectivas para la estimación de la calidad del agua y los hábitats en aguas corrientes de todo el mundo. El estado del río Febros y uno de sus tributarios, la Ribeira de Jaca, han sido evaluados durante un año de controles estacionales en términos de hábitat y de la calidad física, química y biológica de sus aguas, mediante el uso de macroinvertebrados bentónicos como indicadores ecológicos. Estas cuencas fluviales están afectadas por la contaminación que procede de la agricultura, de la industria y de las áreas urbanas. Ambas corrientes de agua están de moderada a severamente degradadas, con variabilidad temporal y espacial de las comunidades de macroinvertebrados y de la calidad del agua. Las malas condiciones generales de la zona fluvial estudiada son especialmente aparentes en la parte alta de Ribeira de Jaca que está afectada por instalaciones industriales. Este punto presenta temperaturas, conductividades y sólidos disueltos más elevados que en los demás lugares estudiados. Las mejores condiciones se hallaron en el área del Parque Biológico de Gaia, donde el hábitat se 
puede evaluar como bueno y los índices bióticos indican que la calidad del agua es excelente y buena, respectivamente, durante la primavera y el verano. No obstante, incluso esta localización presenta valores de indicadores biológicos que apuntan a una severa degradación en otoño e invierno. La diversidad de macroinvertebrados es particularmente baja en las muestras de verano y otoño con poblaciones dominadas por taxones que toleran la contaminación, como los Chironomidae. Los valores de abundancia son generalmente más elevados en primavera y más bajos en invierno. El porcentaje de Ephemeroptera y Trichoptera (EPT) es bajo, alcanzando un 31 \% entre ambos grupos. Los Plecoptera se encuentran completamente ausentes en todas las muestras. El porcentaje EPT y de Chironomidae están relacionados con la temperatura y la Demanda Bioquímica de Oxígeno (BOD). La calidad de este hábitat y la de sus sistemas biológicos ha mejorado en relación con anteriores estudios. El presente trabajo debe ayudar a identificar las medidas específicas necesarias para recuperar la calidad del hábitat y de su agua hasta condiciones de referencia.

Palabras clave: Índices bióticos, indicadores ecológicos, macroinvertebrados bentónicos, calidad de agua.

\section{INTRODUCTION}

The characterisation of the whole ecosystem is essential to assess river conditions and define possible rehabilitation measures, where needed, and to evaluating ecosystem responses to pollution. Ideally, the quality of running waters should be evaluated using physical, chemical and biological parameters to obtain a complete range of information. Habitat evaluation is also critical because aquatic fauna often have habitat requirements that are independent of water quality (Barbour et al., 1996). This finding has been acknowledged in the EU Water Framework Directive (EC, 2000) in which assessment and monitoring of the state of water bodies is no longer restricted to evaluating their use; the ecological state must also be considered analysing biological parameters along with hydromorphological and physicochemical parameters.

The evaluation of river conditions using biotic communities is based on the assumption that disturbances produce structural modifications in these communities, changing density and distribution or causing functional changes in the ecosystem (Alba-Tercedor and SánchezOrtega, 1988). Organisms interact with numerous physicochemical conditions, showing their combined effects, and organisms accumulate these effects over time, indicating the ecosystem effects of water quality (Karr, 1999; Bernardino et al., 2000; Cortes et al., 2002). Benthic macroinvertebrates are commonly used for biological wa- ter quality assessment (e.g., Metcalfe, 1989; Pires et al., 2000; Hering et al., 2003; Park et al., 2003; Pinto et al., 2004; Haidekker and Hering, 2008; Królak and Korycińska, 2008; Leunda et al., 2009) because they live in the waterbottom substrate interface, interacting with both, can be found in various types of (micro)habitats, include taxa with different degrees of sensitivity towards pollution, are sedentary or of reduced mobility and have relatively long life cycles allowing for the assessment of past or longterm exposures. Furthermore, macroinvertebrates are easy and cheap to collect, easily identified, and their reaction to environmental conditions is well established. They provide information about the general state of the lotic ecosystem, the impact of pollutants on the biocenoses and the self-cleaning capacity of the water body (Cook, 1976; Resh et al., 1996). Macroinvertebrates are used at different levels: to study their taxonomic composition or abundance, diversity and equitability; to study certain macroinvertebrate groups (e.g., functional groups); or in computing biotic indices (Armitage et al., 1983; De Pauw and Vanhooren, 1983; Alba-Tercedor, 1996; Morais et al., 2004) that provide important information on community structure (Adams et al., 2005). Biological potential is limited by the quality of the physical habitat. Habitat assessment implies the evaluation of the structure of the surrounding physical habitat that influences the quality of the water resource and the condition of the resident aquatic commu- 


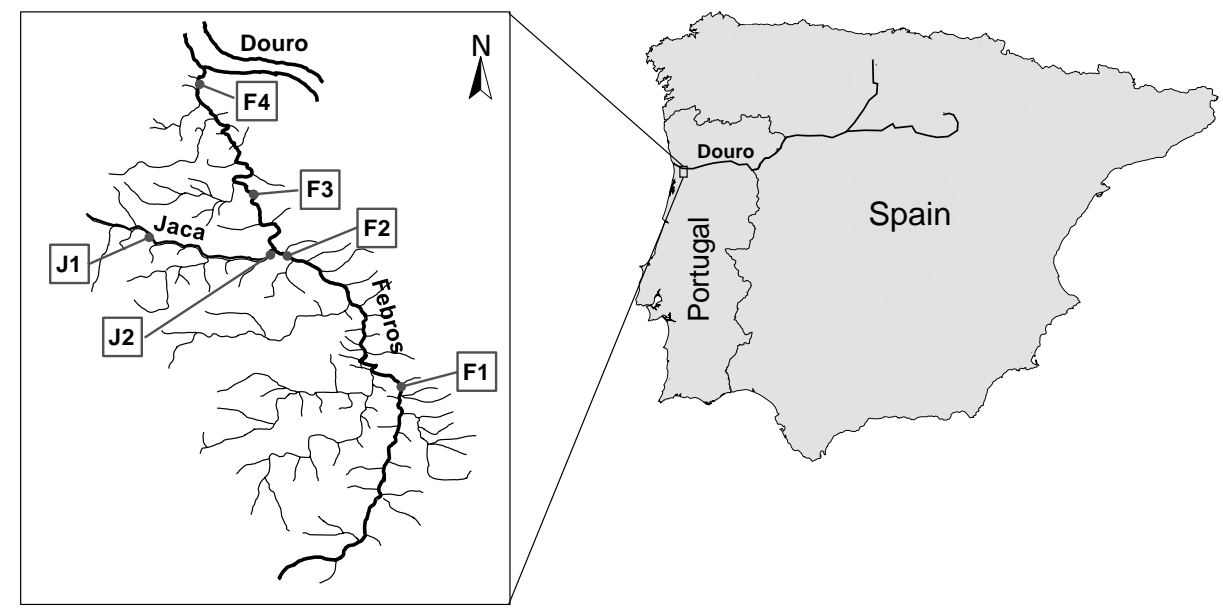

Figure 1. Location of the Febros River in northern Portugal and the six sampling sites in the Febros River (F1 to F4) and in its tributary, Jaca Creek (J1 and J2). Localización del río Febros en el norte de Portugal y de los seis puntos de muestreo en el río Febros (F1 a F4), y de su tributario el arroyo Jaca (J1 y J2).

nity (Barbour et al., 1996; Oliveira and Cortes, 2005). For streams, an holistic approach to assessing habitat structure includes an evaluation of the variety and quality of the substrate, channel morphology, bank structure and riparian vegetation (Munné et al., 2003; Barbour et al., 1999).

A major chloridric acid spill accident in Jaca Creek in August 2008 caused a sudden drop in $\mathrm{pH}$ to 3.5 that fortunately only persisted for a few hours. The present study was set up following this event to characterise the ecological state of the Febros River and its tributary, Jaca Creek, using benthic macroinvertebrate communities, habitat and physical and chemical water quality parameters. We analysed seasonal and spatial patterns and tested whether macroinvertebrate diversity and composition, as well as macroinvertebrate-based biotic indices, were related to physicochemical water and habitat conditions. The results were further compared to reference conditions (Fontoura, 1990; Caldas, 1999).

\section{METHODS}

\section{Study Area}

Located in northern Portugal $\left(41^{\circ} 07^{\prime} \mathrm{N}\right.$, $\left.08^{\circ} 34^{\prime} \mathrm{W}\right)$, the Febros River is the last left- bank tributary of the Douro River (Fig. 1). The river is $14.8 \mathrm{~km}$ long, running from Lugar das Corgas (Seixezelo) to Cais do Esteiro (Avintes), and has a basin occupying $35.4 \mathrm{~km}^{2}$. The riverbanks are steep in the upper sections, becoming gradually less abrupt, with widening banks in the lower areas (Pedrosa et al., 1985). Protected from Atlantic winds by the topography, most of the land adjacent to the river margins has been occupied by agriculture. In recent decades, however, this activity has declined while urban and industrial development has increased. Consequently, fish species diversity has decreased (Valente, 1990; Costa, 2008), and riparian vegetation exhibits a varying diversity, which is higher in the middle sections, especially in the area of the Biological Park. Local climate is considered to be maritime-Atlantic, with an average annual precipitation of $1149 \mathrm{~mm}$ and with maximum and minimum values in January and August, respectively.

Sampling took place at four sites along the Febros River - Rio de Lobo (F1), Ponte Pereiro (F2), Parque Biológico (F3) and Outeiro (F4) - and at two sites in one of its tributaries, Jaca Creek - one upstream (J1) and one downstream (J2) (Fig. 1). This tributary is highly modified with its margins mainly occupied by industries, urban complexes and one urban highway. 


\section{Habitat and physicochemical environment}

The ecological quality of the riparian habitat was assessed in situ using the Ecological Quality of Riparian Habitat for rivers and streams, or QBR, index (Munné et al., 1998; Munné et al., 2003). The index can be used to contrast sites, to compare sites to reference conditions, or to assess the success of restoration projects over time (Chaves et al., 2006).

Water was sampled monthly, from November 2008 to October 2009, with the exception of September 2009, at the six sampling sites. Water temperature $\left({ }^{\circ} \mathrm{C}\right), \mathrm{pH}$, water dissolved oxygen $(\mathrm{DO}, \mathrm{mg} / \mathrm{l})$, total dissolved solids (TDS, $\mathrm{ppm})$ and electrical conductivity $(\mathrm{EC}, \mu \mathrm{S} / \mathrm{cm})$ were measured in situ. Water samples were collected, cooled and transported to the laboratory for the determination of nitrates $\left(\mathrm{NO}_{3}^{-}, \mathrm{mg} / \mathrm{l}\right)$, nitrites $\left(\mathrm{NO}_{2}^{-}, \mathrm{mg} / \mathrm{l}\right)$, ammonia $\left(\mathrm{NH}_{4}^{+}, \mathrm{mg} / \mathrm{l}\right)$, phosphates $\left(\mathrm{PO}_{4}^{3-}, \mathrm{mg} / \mathrm{l}\right)$ and total chlorine $\left(\mathrm{Cl}^{-}\right.$, $\mathrm{mg} / \mathrm{l}$ ) using a C-200 multi-parameter photometer (Hanna Instruments). Biochemical oxygen demand $\left(\mathrm{BOD}_{5}, \mathrm{mg} / \mathrm{l}\right)$ was determined according to the APHA (1992) protocol.

\section{Macroinvertebrates}

Benthic macroinvertebrates were sampled seasonally (November 2008 and February, May and August 2009) at the six sampling sites using the methodology described by INAG (2008). Samples were preserved in situ with $4 \%$ formaldehyde, transported to the laboratory and rinsed through a battery of sieves with decreasing mesh size $(1000 \mu \mathrm{m}$ to $500 \mu \mathrm{m})$. The organisms were sorted on a white tray and preserved in $70 \%$ ethanol prior to the identification of the taxonomic level required by the proposed indices (Cortes et al., 2002).

Spatial and temporal variability of macroinvertebrate communities were analysed in terms of macroinvertebrate abundance, taxon richness, Shannon-Wiener index $\left(\mathrm{H}^{\prime}\right)$, Pielou's equitability (E), percentage of Chironomidae, and percentage of Ephemeroptera, Plecoptera and Trichoptera (\% EPT). The Biotic Belgian Index (BBI; De Pauw and Vanhooren, 1983) and the Iberian Bi- ological Monitoring Working Party (IBMWP; Alba-Tercedor and Sánchez-Ortega, 1988; AlbaTercedor, 1996) were used. We also calculated the $\operatorname{IPtI}_{N}$ (Northern Portuguese Index of Invertebrates), which, according to the intercalibration exercise of the geographic Mediterranean group, should be used to evaluate the ecological state of Portuguese northern rivers based on macroinvertebrates (INAG, 2009). The Ecological Quality Ratio (EQR) is obtained dividing the $\mathrm{IPtI}_{N}$ value by the reference value for the specific type of river. We used a reference value of 1.02 for small northern rivers, with an EQR $>0.87$ considered as excellent (I), 0.65-0.87 good (II), 0.440.65 reasonable (III), $0.22-0.44$ moderate (IV) and $<0.22$ bad (V) (INAG, 2009).

\section{Statistical Data analysis}

Spatial and seasonal variations of physicochemical water characteristics were analysed. Because most variables failed the Shapiro-Wilk normality test, mean values were compared using the Kruskall-Wallis test followed by the post-hoc pairwise Wilcoxon rank sum tests, corrected for multiple testing, to see which groups of samples differed (Hollander and Wolfe, 1973). Correlations between physicochemical parameters were assessed using Spearman's rank correlation coefficients. Samples were further submitted to a correlation-based principal component analysis (the DCA gradient length was $<0.5$ ) for a multivariate assessment of water quality after a priori elimination of TDS, which were extremely correlated with EC $(r=0.989)$. An NMDS on normalised and standardised variables and a two-way crossed analysis of similarity (ANOSIM), with seasons and sites as factors, were used to discriminate between seasons and sites. ANOSIM $R$ values $<0.25$ are commonly accepted to imply very poor distinction and almost complete overlap between groups, and values of $R>0.75$ indicate good discrimination and no overlap between groups.

Biological indices (i.e., macroinvertebrate abundances, number of taxa, $\mathrm{H}^{\prime}, \mathrm{E}, \%$ Chironomidae, \% EPT, BBI and IBMWP) were not normally distributed. Their overall seasonal variation 
was analysed using the same methods as for the physicochemical variables but pooling the data from all sites. Correlations between biological indices and physicochemical variables were assessed using Spearman's rank correlation coefficients.

Variations in macroinvertebrate communities were assessed through a 2D NMDS (stress = 0.12 ) based on log-transformed macroinvertebrate abundance data and Bray-Curtis similarities. Sample distribution was related to the seasonal (November, February, May and August) values of the physicochemical variables and to biotic indexes, plotted as supplementary variables. ANOSIM was used to discriminate between seasons, pooling samples from all sites, and between sites, pooling all seasons.
Principal component and redundancy analyses were performed using CANOCO 4.5 (Ter Braak and Smilauer, 1998), NMDS and analyses of similarity using CANOCO-WinKyst and Primer (Clarke and Green, 1988; Clarke, 1993). All other analyses were done in $R$ (R Dev. Core Team, 2005). For all tests, a significance of $\alpha=0.05$ was considered.

\section{RESULTS}

\section{Habitat and physicochemical environment}

According to the QBR, river habitat conditions were mostly poor, with three extremely degraded

Table 1. Habitat and biological parameters by sample site and season, with the observed number of macroinvertebrate taxa and individuals (Ind.), Belgian Biotic index (BBI), Iberian Bio-Monitoring Working Party index (IBMWP), Ecological Quality Ratio (EQR) and Riparian Habitat Ecological Quality index (QBR), with classes I to V for non- to severely degraded conditions; ShannonWiener diversity index $\left(\mathrm{H}^{\prime}\right)$ and Pielou equitability index (E). Hábitat y parámetros ecológicos por muestra, localización y estación, con: número de taxones de macroinvertebrados observados, así como el número de sus individuos (Ind.); índice Belgian Biotic (BBI), índice Iberian Bio-Monitoring Working Party (IBMWP), tasa de calidad ecológica (EQR) e indice Riparian Habitat Ecological Quality (QBR), definidos con las clases de I a V para condiciones de degradación no severa; índice de diversidad de Shannon-Wiener $\left(H^{\prime}\right)$ e índice de equitatividad de Pielou $(E)$.

\begin{tabular}{|c|c|c|c|c|c|c|c|c|c|c|c|}
\hline \multirow{2}{*}{ Site } & \multirow{2}{*}{ Season } & \multirow{2}{*}{ Taxa } & \multirow{2}{*}{ Ind. } & \multicolumn{2}{|c|}{ BBI } & \multicolumn{2}{|c|}{ IBMWP } & \multicolumn{2}{|c|}{ EQR } & \multirow{2}{*}{$\mathrm{H}^{\prime}$} & \multirow{2}{*}{$\mathrm{E}$} \\
\hline & & & & Score & Class & Score & Class & Score & $\overline{\text { Class }}$ & & \\
\hline $\mathrm{F} 1$ & Aut. & 8 & 185 & 5 & III & 34 & IV & 0.46 & III & 1.55 & 0.59 \\
\hline Rio de Lobo & Win. & 10 & 221 & 5 & III & 37 & III & 0.55 & III & 1.71 & 0.55 \\
\hline QBR score $=0$ & Spr. & 14 & 6991 & 7 & II & 55 & III & 0.54 & III & 1.40 & 0.46 \\
\hline class $=\mathrm{V}$ & Sum. & 13 & 1896 & 6 & III & 61 & II & 0.61 & III & 1.10 & 0.36 \\
\hline $\mathrm{F} 2$ & Aut. & 10 & 1404 & 5 & III & 40 & III & 0.38 & IV & 1.24 & 0.46 \\
\hline Ponte Pereiro & Win. & 7 & 106 & 5 & III & 21 & IV & 0.39 & IV & 1.63 & 0.56 \\
\hline QBR score $=40$ & Spr. & 28 & 5915 & 8 & II & 132 & I & 0.77 & II & 1.45 & 0.40 \\
\hline class $=\mathrm{IV}$ & Sum. & 19 & 4013 & 8 & II & 83 & II & 0.76 & II & 1.87 & 0.57 \\
\hline F3 & Aut. & 12 & 1282 & 6 & III & 45 & III & 0.44 & III & 1.62 & 0.62 \\
\hline Parque Biológico & Win. & 6 & 145 & 6 & III & 20 & IV & 0.37 & IV & 1.48 & 0.62 \\
\hline QBR score $=80$ & Spr. & 23 & 3244 & 9 & I & 107 & I & 0.69 & II & 1.64 & 0.48 \\
\hline class $=$ II & Sum. & 19 & 4100 & 8 & II & 86 & II & 0.63 & III & 0.88 & 0.27 \\
\hline F4 & Aut. & 13 & 1662 & 7 & II & 41 & III & 0.36 & IV & 1.29 & 0.48 \\
\hline Outeiro & Win. & 6 & 122 & 5 & III & 18 & IV & 0.25 & IV & 0.85 & 0.37 \\
\hline QBR score $=0$ & Spr. & 16 & 8657 & 8 & II & 62 & II & 0.52 & III & 1.07 & 0.35 \\
\hline class $=\mathrm{V}$ & Sum. & 17 & 2264 & 7 & II & 63 & II & 0.55 & III & 1.55 & 0.49 \\
\hline $\mathrm{J} 1$ & Aut. & - & - & 一 & 一 & - & 一 & - & - & - & - \\
\hline Jaca Creek upstream & Win. & 2 & 840 & 2 & $\mathrm{~V}$ & 3 & $\mathrm{~V}$ & 0.00 & $\mathrm{~V}$ & 0.08 & 0.07 \\
\hline QBR score $=0$ & Spr. & 8 & 4559 & 5 & III & 22 & IV & 0.24 & IV & 0.77 & 0.31 \\
\hline class $=\mathrm{V}$ & Sum. & 12 & 1692 & 7 & II & 45 & III & 0.45 & III & 1.48 & 0.60 \\
\hline $\mathrm{J} 2$ & Aut. & 11 & 495 & 5 & III & 39 & III & 0.33 & IV & 1.35 & 0.51 \\
\hline Jaca Creek downstream & Win. & 4 & 39 & 4 & IV & 10 & $\mathrm{~V}$ & 0.16 & $\mathrm{~V}$ & 0.88 & 0.63 \\
\hline QBR score $=55$ & Spr. & 8 & 1792 & 5 & III & 33 & IV & 0.36 & IV & 1.40 & 0.61 \\
\hline class $=$ III & Sum. & 8 & 3647 & 5 & III & 26 & IV & 0.27 & IV & 1.42 & 0.55 \\
\hline All & & 58 & 55271 & & & & & & & & \\
\hline
\end{tabular}



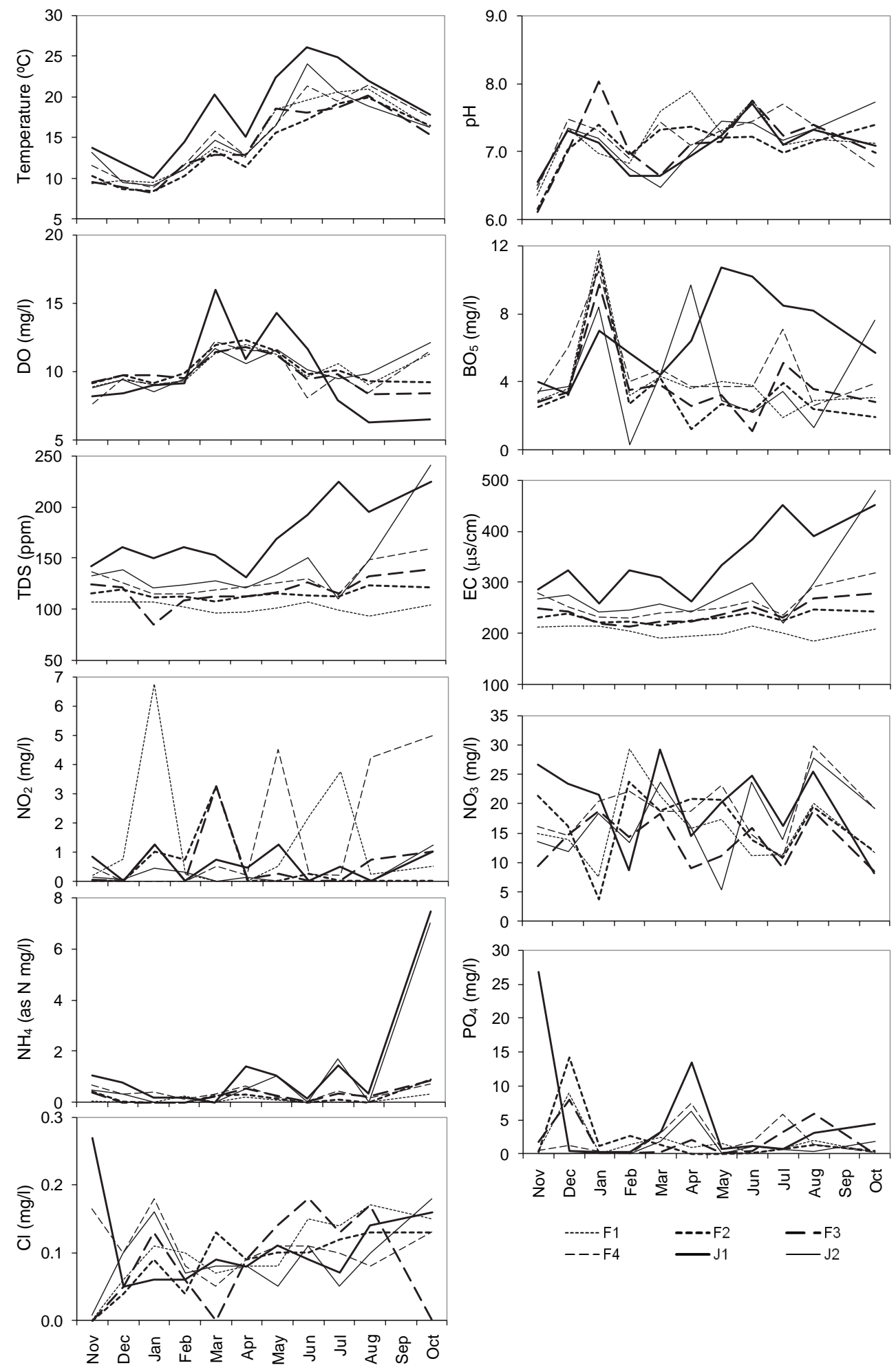

$\begin{array}{lll}----F 2 & --F 3 \\ ---F 4 & -J 1 & -J 2\end{array}$

Figure 2. Monthly physicochemical water quality in the Febros River (F1-F4) and Jaca Creek (J1-J2). Calidad fisicoquímica mensual del agua del río Febros (F1-F4) y del arroyo Jaca (J1-J2). 
sites $-\mathrm{F} 1, \mathrm{~F} 4$ and $\mathrm{J} 1 . \mathrm{F} 2$ and $\mathrm{J} 2$ showed poor and fair habitat quality, respectively. The QBR value obtained for F3, located in the Gaia Biological Park, indicated good habitat quality with slight disturbances (Table 1).

Water physicochemical conditions were excellent in terms of $\mathrm{pH}$ and $\mathrm{DO}$ concentration (Fig. 2). EC and TDS values were good, though they were higher for $\mathrm{J}_{1}$. $\mathrm{BOD}_{5}$ showed various peaks indicating bad quality, which in December occurred at all sites. Nutrient concentrations showed some variability, indicating overall reasonable quality for $\mathrm{NH}_{4}^{+}, \mathrm{NO}_{2}^{-}$and $\mathrm{NO}_{3}^{-}$, but extremely poor quality considering $\mathrm{PO}_{4}^{3-}$.

Testing the spatial variability of physiochemical variables by season (Kruskall-Wallis tests), we observed significant ( $\alpha=0.05)$ differences between sites for EC and TDS in the winter and autumn and for $\mathrm{EC}, \mathrm{TDS}$ and $\mathrm{BOD}_{5}$ in the spring. Summer samples showed no significant spatial differences. Only F2, F3 and J1 showed seasonal variability for $\mathrm{NO}_{2}^{-}, \mathrm{BOD}_{5}$ and $\mathrm{DO}$, respectively. No pair-wise significant differences were found (probably due to the small sample size).

Overall, J1 had the worst water quality, with consistently high $\mathrm{BOD}_{5}$ values from spring to autumn and higher EC and TDS values, particularly during summer and autumn (Fig. 2). This was also reflected in the PCA (Fig. 3), which showed a water quality gradient $\left(\mathrm{EC}, \mathrm{BOD}_{5}\right.$, and $\mathrm{Cl}^{-}$and $\mathrm{NH}_{4}^{+}$) on the first axis, separating most $\mathrm{J} 1$ samples and one $\mathrm{J} 2$ autumn sample from the other sites. The second axis was predominantly seasonal, separating samples with different temperatures, DO concentrations and $\mathrm{pH}$. According to the two-way crossed ANOSIM applied to the standardised Euclidean distance MDS (stress $=0.17$ ), there were significant differences between sites (global $R=0.123$ and $p=0.01)$; J1 was distinct from all other sites except for F4, and $\mathrm{J} 2$ and F3 were distinct from F1 (all $R>0.300$ and $p<0.05$ ). There were also significant differences between seasons (global $R=0.123$ and $p=0.01$ ), with only autumn distinct from all other seasons $(R>0.170$ and $p<0.05)$. Spatial and temporal clusters were, however, strongly overlapping.

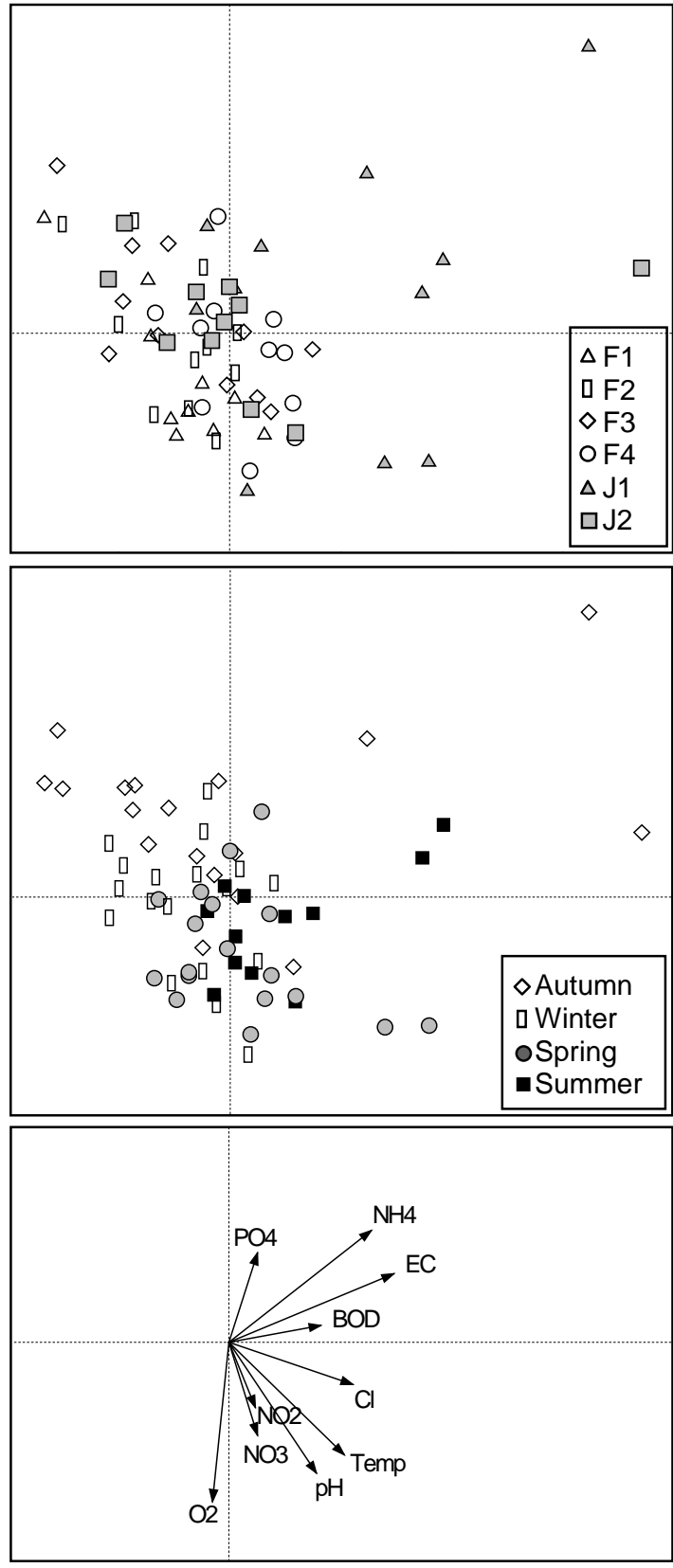

Figure 3. The first two axes of the PCA applied to the monthly physicochemical parameters; samples are marked according to the sampling site (upper plot; F: Febros River, J: Jaca Creek) and season (central plot); parameters are plotted separately for ease of visualisation (lower plot). Representación de los dos primeros ejes del PCA aplicado a los parámetros fisicoquímicos mensuales. Las muestras están marcadas por el punto de muestreo (gráfico superior; F: río Febros, J: arroyo Jaca) y por la estación (gráfico central). En el gráfico inferior los prámetros se presentan por separado para una visualización más sencilla. 
Table 2. Macroinvertebrate taxa, the number of samples with occurrences (Occ., in a total of 24 samples) and the total number of individuals (Ind.) found. Taxones de macroinvertebrados, número de muestras con aparición del taxón (Occ.; en un total de 24 muestras) y número total de individuos (Ind.) hallados.

\begin{tabular}{|c|c|c|c|c|}
\hline Order/Sub-order & Family & Genus & Occ. & Ind. \\
\hline \multirow[t]{8}{*}{ O. Trichoptera } & Curculionidae & & 1 & 2 \\
\hline & Ecnomidae & & 1 & 6 \\
\hline & Glossosomatidae* & & 1 & 5 \\
\hline & Hydropsychidae & & 15 & 392 \\
\hline & Hydroptilidae* & & 4 & 443 \\
\hline & Limnephilidae* & & 1 & 3 \\
\hline & Polycentropodidae & & 3 & 14 \\
\hline & Rhyacophilidae & & 8 & 96 \\
\hline \multirow[t]{5}{*}{ O. Ephemeroptera } & Baetidae & Baetis & 21 & 15578 \\
\hline & Baetidae & Acentrella & 3 & 39 \\
\hline & Caenidae & Caenis & 9 & 389 \\
\hline & Ephemerellidae & Ephemerella & 3 & 55 \\
\hline & Leptophlebiidae & Habrophlebia & 3 & 18 \\
\hline \multirow[t]{5}{*}{ O. Odonata } & Aeshnidae & Aeshna & 4 & 17 \\
\hline & Calopterygidae & Calopteryx & 5 & 32 \\
\hline & Cordulegasteridae & Cordulegaster & 1 & 2 \\
\hline & Gomphidae & Onychogomphus & 1 & 2 \\
\hline & Gomphidae & Ophiogomphus & 1 & 2 \\
\hline \multirow[t]{3}{*}{ O. Heteroptera } & Gerridae & Gerris & 1 & 5 \\
\hline & Mesoveliidae & Mesovelia & 1 & 4 \\
\hline & Nepidae & Nepa & 1 & 3 \\
\hline \multirow[t]{6}{*}{ O. Coleoptera } & Chrysomelidae & & 1 & 7 \\
\hline & Dryopidae & & 1 & 12 \\
\hline & Dysticidae & & 1 & 11 \\
\hline & Elmidae & & 4 & 45 \\
\hline & Haliplidae & & 1 & 8 \\
\hline & Hydrophilidae & & 2 & 6 \\
\hline \multirow[t]{13}{*}{ O. Diptera } & Anthomyidae & & 2 & 4 \\
\hline & Athericidae & & 8 & 155 \\
\hline & Ceratopogonidae & & 6 & 100 \\
\hline & Chironomidae (non TP group) ${ }^{1}$ & & 23 & 19256 \\
\hline & Chironomidae (TP group) ${ }^{2}$ & & 4 & 330 \\
\hline & Dixidae & & 2 & 4 \\
\hline & Dolicophodidae & & 1 & 2 \\
\hline & Empididae & & 9 & 87 \\
\hline & Ephydridae & & 1 & 2 \\
\hline & Psychodidae & & 9 & 53 \\
\hline & Sciomyzidae & & 1 & 61 \\
\hline & Simuliidae & & 16 & 3589 \\
\hline & Tipulidae & & 5 & 18 \\
\hline O. Isopoda & Asellidae & Asellus & 4 & 25 \\
\hline
\end{tabular}

* Trichoptera with cases, thus more sensitive.

${ }^{1}$ Chironomidae that are not of the thummi plumosus group, less tolerant to pollution.

${ }^{2}$ Chironomidae of the thummi plumosus group, more tolerant to pollution. 
Table 2. (cont.)

\begin{tabular}{|c|c|c|c|c|}
\hline Order/Sub-order & Family & Genus & Occ. & Ind. \\
\hline \multirow[t]{9}{*}{ Cl. Gastropoda } & Ancylidae & Ancylus & 2 & 8 \\
\hline & Bithyniidae & Bithynia & 3 & 10 \\
\hline & Discidae & Discus & 1 & 3 \\
\hline & Hydrobiidae & Bithynella & 6 & 105 \\
\hline & Hydrobiidae & Potamopyrgus & 20 & 7743 \\
\hline & Lymnaeidae & Galba & 2 & 8 \\
\hline & Lymnaeidae & Radix & 5 & 39 \\
\hline & Physidae & Physa & 14 & 558 \\
\hline & Planorbidae & Gyraulus & 1 & 4 \\
\hline \multirow[t]{3}{*}{ Cl. Bivalvia } & Sphaeriidae & Pisidium & 1 & 2 \\
\hline & Sphaeriidae & Sphaerium & 1 & 2 \\
\hline & Valavatidae & Valvata & 1 & 7 \\
\hline Cl. Oligochaeta & & & 22 & 5881 \\
\hline \multirow[t]{3}{*}{ Cl. Hirudinea } & Erpobdellidae & Dina & 1 & 3 \\
\hline & Erpobdellidae & Erpobdella & 3 & 10 \\
\hline & Glossiphoniidae & Glossiphonia & 1 & 2 \\
\hline O. Triclada & Planariidae & Polycelis & 1 & 4 \\
\hline
\end{tabular}

EC and TDS were significantly positively correlated with each other (0.989) and with temperature $(>0.300)$ and $\mathrm{NH}_{4}-\mathrm{N}(>0.400)$.

\section{Macroinvertebrates}

A total of 58 macroinvertebrate taxa were identified (Table 2), but 25 of them occurred only once. Macroinvertebrate taxon richness and abundances were generally lowest in winter and highest in spring (Table 1).
Biotic indixes varied from non-polluted conditions - for the F2 and F3 spring samples - to severely polluted conditions - for the J1 and $\mathrm{J} 2$ winter samples. Spring and summer samples tended to have better scores for F2, F3 and F4.

The EQR also varied by season and by site, showing similar patterns. F1 displayed little seasonal variability and reasonable conditions. F2, F3 and F4 showed better conditions in spring and summer in comparison to autumn and winter, ranging from good to medium for F2 and F3

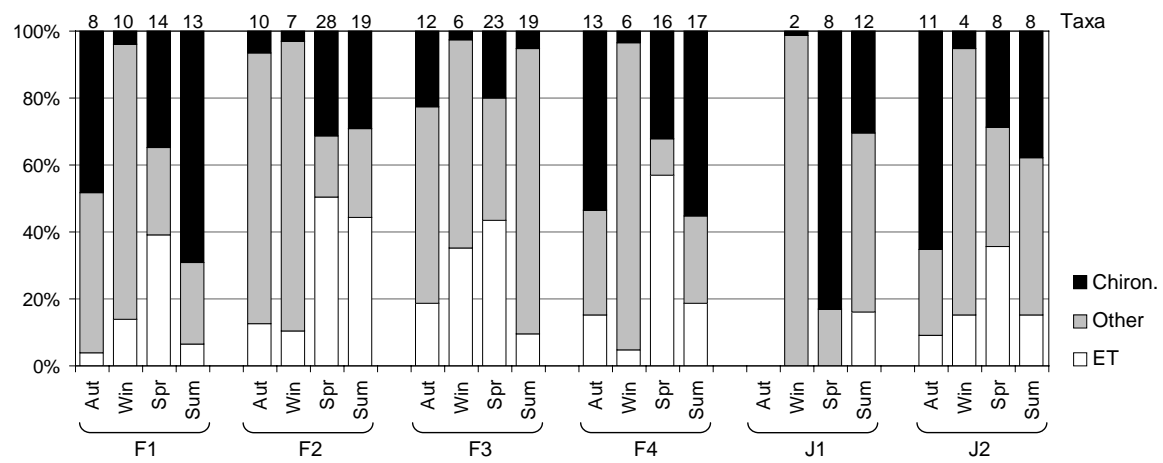

Figure 4. Total number of taxa and percentages of Chironomidae (Chiron.) and Ephemeroptera and Tichoptera (ET; Plecoptera were absent) in the Febros River (F1-F4) and Jaca Creek (J1-J2); Aut: Autumn, Win: Winter, Spr: Spring, Sum: Summer. Número total de taxones de quironómidos y sus pocentajes (Chiron.); y de efemerópteros y ticópteros (ET; no se encontraron plecópteros) en el río Febros Febros (F1-F4) y el arroyo Jaca (J1-J2); Aut: otoño, Win: invierno, Spr:primavera, Sum: verano. 
and from reasonable to medium for F4. The Jaca Creek sites were the most different from reference conditions (medium to bad conditions), especially for the winter samples.

Macroinvertebrate diversity was poor and Shannon-Wiener index $(\mathrm{H})$ and Pielou Equitability Indexes low. The \% EPT (Plecoptera were always absent) was variable, mostly higher in the spring; the \% Chironomidae was also variable but mostly lower in winter (Fig. 4). The upstream site in Jaca Creek had 0 to $16 \%$ EPT and up to $83 \%$ of Chironomidae. Seasonal differences for the number of macroinvertebrate taxa and abundances, IBB, IBMWP, \% Chironomidae and EQR were significant, though no pair-wise significant differences were found (probably due to the small sample size).

The NMDS ordination of macroinvertebrate abundances (stress $=0.12$ ) showed a first axis with a seasonal gradient (Fig. 5). Plotting physicochemical and biological indicator variables as supplementary variables within the macroinvertebrate ordination space, we see that this first axis separates the colder winter samples, with less taxa, lower abundances, poorer biological water quality and higher nutrient concentrations, from the summer and spring, as well as most of the autumn data. Spatial patterns were vague, though $\mathrm{J} 1$ and $\mathrm{J} 2$ samples tended to be in the section with lower biological water quality. ANOSIM, pooling sites per season, showed clear seasonal patterns $(R=0.541, p=0.001)$. Except for the spring and summer pair, all seasons were well discriminated $(R>0.285, p<0.024)$, particularly winter and summer $(R=0.926, p=0.002)$. No significant spatial discrimination (pooling all seasons for each site) was found.

As expected, most biological indicators, particularly IBB and IBMWP, were strongly positively correlated with each other (0.892) and with the number of taxa, observed abundances, \% EPT and EQR (all >0.560); EQR was strongly positively correlated with the number of taxa and macroinvertebrate abundances, and abundances were strongly positively correlated with the number of taxa. Abundances and the number of taxa were further positively correlated with \% Chironomidae, \% EPT and EQR. The only signif-

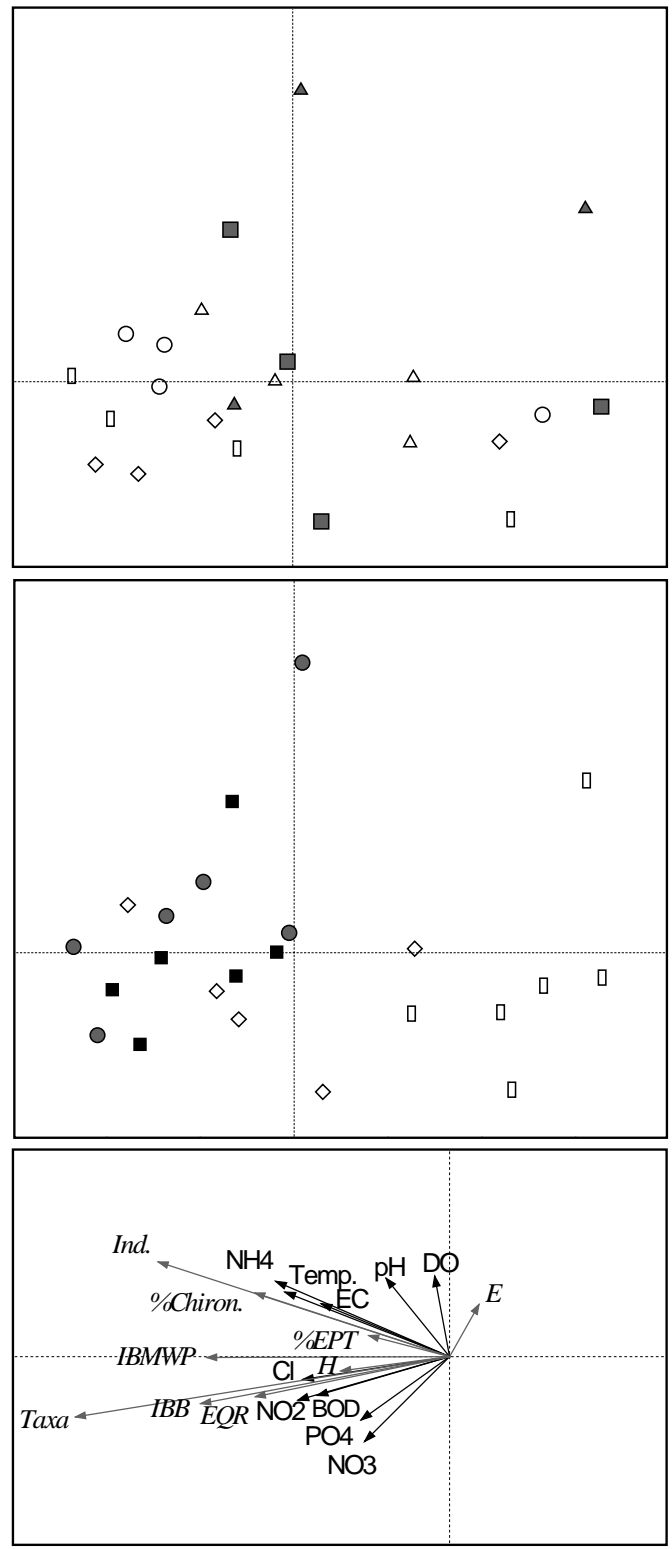

Figure 5. NMDS ordination of macroinvertebrate abundances; samples are marked according to the sampling site (upper plot; F: Febros River, J: Jaca Creek) and season (central plot); physicochemical variables and biological indices are overlayed as supplementary variables in a separate plot for ease of visualisation (lower plot; Temp.: temperature, EC: electrical conductivity, Chiron.: Chironomidae). Representación de las posiciones NMDS de las abundancias de macroinvertebrados. Las muestras están marcadas por el punto de muestreo (gráfico superior; F:río Febros, J: arroyo Jaca) y por la estación (gráfico central). Las variables fisicoquímicas y los índices biológicos están superpuestos como variables suplementarias en un gráfico separado para una visualización más sencilla. (gráfico inferior; Temp.: temperatura, EC: conductividad eléctrica, Chiron.: quironómidos). 
icant negative correlation found was between $\mathrm{E}$ and macroinvertebrate abundances. Relating biological variables to physicochemical variables, temperature was significantly positively correlated with IBB, IBMWP, \% Chironomidae, taxa and abundances. Furthermore, $\mathrm{pH}$ was positively correlated with macroinvertebrate abundances, and $\mathrm{BOD}_{5}$ was negatively correlated with $\mathrm{E}$.

\section{DISCUSSION}

The Febros River and its tributary, Jaca Creek, display a wide range of habitats, physicochemical and biotic conditions, depending on natural and anthropogenic factors and local conditions.

Jaca Creek, and particularly its upper area, showed the poorest water quality, most likely caused by industrial and urban pollution. The poorer condition of this site is aggravated by the reduced brook size and water flow, especially during summer, and the resulting poor depuration capacity. Though water is well oxygenated here, it has high EC, TDS and nutrient concentrations, particularly phosphates, suggesting industrial and domestic pollution fertilisation.

In the Febros River, the water physicochemical parameters (DO and corresponding \% of saturation, $\mathrm{BOD}_{5}$, nitrates, $\mathrm{pH}$ and ammonia) correspond to a good ecological state for northern typology rivers (INAG, 2009), again with the exception of $\mathrm{F} 4$, where $\mathrm{DO}$ (and \% saturation) and $\mathrm{BOD}_{5}$ values exceeded the established limits in March and December 2009. This downstream site also showed severe habitat degradation, the highest EC/TDS values and higher nutrient concentrations than the upstream sites, probably caused by accumulated diffuse agricultural pollution. Several authors have indicated that the increase in ammonia concentration in aquatic ecosystems induces a decrease in the abundance of benthic invertebrates (Versteeg et al., 1999). Jaca Creek showed high ammonia concentrations and low macroinvertebrate abundances, and many of the macroinvertebrates present belong to pollution resistant taxa (e.g., Chironomidae). Physicochemical conditions in the Febros River were similar to those of a previous study carried out between 2002 and 2005 (Carvalho, 2008). However, conditions in the Biological Park site have improved since then; there is no longer a steady up- to downstream water quality degradation.

The $\mathrm{pH}$ values measured in the study suggest that, at least in terms of physicochemical conditions, the watercourses have recovered from the chloridric acid spill accident in 2008. The accident surely harmed the benthic macroinvertebrate communities, as many taxa cannot tolerate very low $\mathrm{pH}$ values (Solà et al., 2004). We have, however, no comparable biological data for the before- and after-spill situations to quantify damages and to evaluate the communities' recovery. Looking at Jaca Creek separately, we observed that the biological water quality was much worse upstream than downstream, which could indicate remaining spill damage to the macroinvertebrate communities. Future monitoring will reveal whether these communities fully recover.

The biological quality observed in Jaca Creek was lower than that of the main river course. The Febros River displayed a general gradient of better to worse water quality from up to downstream (F1 to F4), with the exception of the Biological Park section (F3). F3 showed the best overall habitat, physicochemical and biotic conditions, given the abundant riparian vegetation that enhances the buffering capacity and the elimination of pollutants, and provides natural habitats (Moore and Palmer, 2005).

In terms of macroinvertebrates, we observed natural seasonality, with water temperature favouring community diversity in summer and spring. However, diversity was low overall in the Febros River and particularly low in the upstream site at Jaca Creek, suggesting the presence of a stressed macroinvertebrate community disturbed by the observed pollution and, possibly, still recovering from the acid spill in 2008. Environmental degradation causes the simplification of community structure (Mykrä et al., 2008). Next to Chironomidae, Baetidae was the most dominant family in our samples. This family is considered to be in the mid-range for tolerance of most environmental stressors and is generally considered to be tolerant towards sedimentation, nutrient enrichment and organic pollution (Har- 
rington \& Born, 2000; Menetrey et al., 2008), as found in our samples; they are also excellent swimmers and can survive in high-flow environments. Ephemerellidae, which are generally considered to be sensitive to pollution stress (Harrington \& Born, 2000), were rare in our samples. We observed high percentages of Chironomids (midges), which can be either sensitive or tolerant to environmental stressors depending on the species (Stribling et al., 1998), particularly at the more polluted sites but also upstream in the Febros River (F1). Macroinvertebrate diversity and \% EPT were, however, higher than those observed in previous studies (Carvalho, 2008).

Biotic indices (IBB and IBMWP) and EQR followed the general spatial trend in river and river tributary quality. Their scores ranged from good to very poor biological quality in the Gaia Biological Park and at the Jaca Creek sites, respectively, reflecting the observed organic pollution and water quality. For the Febros, biotic indices were overall better than those observed in previous studies (Fontoura, 1990; Caldas, 1999; Carvalho, 2008). Improvement in biological water quality was related to better physicochemical conditions. In the Febros, downstream conditions improved with the implementation of wastewater treatment in 2003, which collected about $70 \%$ of urban effluents by 2006. The Biological Park has been steadily improving habitat and physicochemical conditions, favouring biological water quality. The Febros River had, for instance, on average twice the $\mathrm{BOD}_{5}$ in 2002 and 2005 (Carvalho, 2008) as in 2008/9 (our study).

In conclusion, our observations provide evidence of severely degraded river conditions in several sections of the Febros River and Jaca Creek that would benefit from restoration measures. The river, which once had an abundant brown trout population (Valente, 1990), suffered the effects of continuous pollution until 2003, when the water treatment plant began to operate. In recent years, the earlier increasingly eutrophised river has shown improvements in habitat and biological water quality, particularly in the area of the protected Gaia Biological Park. Its tributary is undoubtedly in a more degraded state, and a recent, severe vegetation cut in the lower stretch may have contributed to further river habitat deterioration after our study.

\section{ACKNOWLEDGEMENTS}

This study was funded by the Parque Biológico de Gaia and the company Tranquilidade. We would further like to thank all students of the Aquatic Environmental Laboratory (Department of Biology, Faculty of Sciences, University of Oporto) for their help during the field and laboratory work.

\section{REFERENCES}

ADAMS, S. M., M. G. RYON \& G. SMITH. 2005. Recovery in diversity of fish and invertebrate communities following remediation of a polluted stream: investigating causal relationships. Hydrobiologia, 542: 77-93.

ALBA-TERCEDOR, J. 1996. Macroinvertebrados Acuaticos y Calidad de las Aguas de los Ríos. IV Simposio del Agua en Andalucia. $2^{\text {nd }}$ Volume, Almeria, Spain: 203-213.

ALBA-TERCEDOR, J. \& A. SANCHÉZ-ORTEGA. 1988. Un método rápido y simples para evaluar la calidad biológica de las aguas corrientes basado en el de Hellawell (1978). Limnetica, 4: 51-56.

APHA -AMERICAN PUBLIC HEALTH ASSOCIATION. 1992. Standard Methods for the Examination of Water and Wastewater. $18^{\text {th }}$ Edition, Washington, DC, USA. $1100 \mathrm{pp.}$

ARMITAGE, P. D., D. MOSS, J. F. WRIGHT \& M. T. FURSE. 1983. The performance of a new biological water quality system based on macroinvertebrates over a wide range of unpolluted runningwater sites. Water Research, 17: 383-387.

BARBOUR, M. T., J. D. DIAMOND \& C. YODER. 1996. Biological assessment strategies: application and limitations. In: Whole-effluent toxicity testing: an evaluation of methods and predictability of receiving system responses. D. R. Grothe, K. L. Dickson \& D. K. Reed (eds.): 245-270. Society of Environmental Toxicology and Chemistry Press, Pensacola, Florida, USA.

BARBOUR, M. T., J. GERRITSEN, B. D. SNYDER \& J. B. STRIBLING. 1999. Rapid bioassessment protocols for use in streams and wade- 
able rivers: periphyton, benthic macroinvertebrates and fish. $2^{\text {nd }}$ Edition, U.S. Environmental Protection Agency, Office of Water, EPA 841-B99-002, Washington, D.C., USA., pp. 234 + Appendices.

BERNARDINO, R., S. RODRIGUES, M. T. RAFAEL, M. H. ALVES \& A. G. HENRIQUES. 2000. Análise Comparativa da Qualidade Ecológica das Águas Superficiais Nacionais tendo como base os Planos de Bacia Hidrográfica. Actas do II Congresso Ibérico sobre Planeamento e Gestão da Água, Porto, Portugal: 1-14.

CALDAS, B. 1999. Caracterização da situação ambiental de referência. Parque Biológico Municipal de Gaia e zona envolvente. Relatório final do Projecto Life, $205 \mathrm{pp}$.

CARVALHO, L. I. 2008. Metodologias para a avaliação integrada dos impactos cumulativos em sistemas fluviais de pequenas bacias sujeitas a elevadas pressões antropogénicas. Dissertação de Doutoramento em Ciências do Meio Aquático. Instituto de Ciências Biomédicas Abel Salazar, Porto, 169 pp.

CHAVES, M. L., J. L. COSTA, P. CHAINHO, M. J. COSTA \& N. PRAT. 2006. Selection and validation of reference sites in small river basins. Hydrobiologia, 573: 133-154.

CLARKE, K. R. \& R. H. GREEN. 1988. Statistical design and analysis for a 'biological effects' study. Mar. Ecol. Progress Series, 46: 213-226.

CLARKE, K. R. 1993. Non-parametric multivariate analyses of changes in community structure. Aust. J. Ecol., 18: 117-143.

COOK, S. E. K. 1976. Quest for an index of community structure sensitive to water pollution. Environ. Pollut., 11: 269-288.

CORTES, R., P. PINTO, M. T. FERREIRA \& I. MOREIRA. 2002. Qualidade biológica dos ecossistemas fluviais. In: Ecossistemas Aquáticos e Ribeirinhos. I. Moreira, M. T. Ferreira, R. M. V. Cortes, P. Pinto \& P. R. Almeida (eds.): 9.3-9.26. Instituto da Água, Ministério das Cidades, Ordenamento do Território e Ambiente, Lisbon, Portugal (in Portuguese).

COSTA, M. J. F. R. 2008. A diversidade ictiofaunística do Rio Febros: da lenta recuperação ao rápido desaparecimento. Dissertação de Mestrado em Hidrobiologia, Faculdade de Ciências da Universidade do Porto, $152 \mathrm{pp}$.
DE PAUW, N. \& G. VANHOOREN. 1983. Method for biological quality assessment of watercourses in Belgium. Hydrobiologia, 100: 153-168.

EC. 2000. Directive 2000/60/EC of the European Parliament and of the Council of 23 October 2000 establishing a framework for Community action in the field of water policy. Official Journal L 327, 22/12/2000: 1-73.

FONTOURA, A. P. 1990. Carta da qualidade biológica da água do Rio Febros (Vila Nova de Gaia). $1^{\circ}$ Congresso Internacional sobre o rio Douro. Observatório, 1: 295-309.

HAIDEKKER, A. \& D. HERING. 2008. Relationship between benthic insects (Ephemeroptera, Plecoptera, Coleoptera, Trichoptera) and temperature in small and medium-sized streams in Germany: A multivariate study. Aquat. Ecol., 42: 463-481.

HARRINGTON, J. \& M. BORN. 2000. Measuring the health of California streams and rivers $-A$ Methods manual for water resource professionals, citizen monitors and natural resource students, $2^{\text {nd }}$ edition, Sustainable Land Stewardship International Institute, Sacramento, California, USA. $276 \mathrm{pp}$.

HERING, D., A. BUFFAGNI, O. MOOG, L. SANDIN, M. SOMMERHÄUSER, I. STUBAUER, C. FELD, R. JOHNSON, P. PINTO, N. SKOULIKIDIS, P. VERDONSCHOT \& S. ZAHRÁDKOVÁ. 2003. The Development of a System to Assess the Ecological Quality of Streams Based on Macroinvertebrates - Design of the Sampling Programme within the AQEM Project. Int. Rev. Hydrobiol., 88: 345361.

HOLLANDER, M. \& D. A. WOLFE. 1973. Nonparametric Statistical Methods. John Wiley, New York. $503 \mathrm{pp}$.

INAG. 2008. Manual para a avaliação biológica da qualidade da água em sistemas fluviais segundo a directiva Quadro da Água. Protocolo de amostragens e análise para os macroinvertebrados bentónicos. Ministério do Ambiente, Ordenamento e do Desenvolvimento Regional. Instituto da Água, I. P. 17 pp.

INAG. 2009. Critérios para a Classificação do Estado das Massas de Água Superficiais-Rios e Albufeiras. Ministério do Ambiente, do Ordenamento do Território e do Desenvolvimento Regional. Instituto da Água, I.P. 29 pp. + Appendices.

KARR, J. R. 1999. Defining and measuring river health. Freshwater Biol., 41: 221-234. 
KRÓLAK, E. \& M. KORYCIŃSKA. 2008. Taxonomic Composition of Macroinvertebrates in the Liwiec River and its Tributaries (Central and Eastern Poland) on the Basis of Chosen Physical and Chemical Parameters of Water and Season. Polish Journal of Environmental Studies, 17: 39-50.

LEUNDA, P. M., J. OSCOZ, R. MIRANDA, H. ARTURO \& A. H. ARIÑO. 2009. Longitudinal and seasonal variation of the benthic macroinvertebrate community and biotic indices in an undisturbed Pyrenean river. Ecol. Indic., 9: 52-63.

MENETREY, N., B. OERTLI, M. SARTORI, A. WAGNER \& J. B. LACHAVANNE. 2008. Eutrophication: are mayflies (Ephemeroptera) good bioindicators for ponds? Hydrobiologia, 597: 125135.

METCALFE, J. L. 1989. Biological water quality assessment of running waters based on macroinvertebrate communities: History and present status in Europe. Environ. Pollut., 60: 101-139.

MOORE, A. A. \& M. A. PALMER. 2005. Invertebrate biodiversity in agricultural and urban headwater streams: implications for conservation and management. Ecological Applications, 15(4): 1169-1177.

MORAIS, M., P. PINTO, P. GUILHERME, J. ROSADO \& I. ANTUNES. 2004. Assessment of temporary streams: the robustness of metric and multimetric indices under different hydrological conditions. Hydrobiologia, 516: 229-249.

MUNNÉ, A., N. PRAT, C. SOLA, N. BONADA \& M. RIERADEVELL. 2003. A Simple Field Method for Assessing the Ecological Quality of Riparian Habitat in Rivers and Streams: A QBR Index. Aquatic Conservation. Marine and Freshwater Ecosystems, 13: 147-163.

MUNNÉ, A., C. SOLÁ \& N. PRAT. 1998. QBR: Un índice rápido para la evaluación de la calidad de los ecosistemas de ribera. Tecnología del Agua, 175: 20-37.

MYKRÄ, H., AROVIITA, J., HÄMÄLÄINEN, H., KOTANEN, J., VUORI, K-M. \& MUOTKA, T. 2008. Assessing stream condition using macroinvertebrates and macrophytes: concordance of community responses to human impact. Archiv für $\mathrm{Hy}$ drobiology, 172(3): 191-203.

OLIVEIRA, S. V. \& R. M. V. CORTES. 2005. A biologically relevant habitat condition index for streams in northern Portugal. Aquatic Conservation: Marine and Freshwater Ecosystems, 15: 189_ 210.
PARK, Y.-S., P. F. M. VERDONSCHOT, T.-S. CHON $\&$ S. LEK. 2003. Patterning and predicting aquatic macroinvertebrate diversities using artificial neural network. Water Res., 37: 1749-1758.

PEDROSA, A. S., F. M. S. T. S. PEDROSA \& J. A. D. TAVARES. 1985. Caracterização Geográfica do Concelho de Vila Nova de Gaia. História de Gaia, fasc. 1, 2 e 3, GHAVNG, Vila Nova de Gaia.

PINTO, P., J. ROSADO, M. MORAIS \& I. ANTUNES. 2004. Assessment methodology for southern siliceous basins in Portugal. Hydrobiologia, 516: 191-214.

PIRES, A. M., I. G. COWX \& M. M. COELHO. 2000. Benthic macroinvertebrate communities of intermittent streams in the middle reaches of the Guadiana Basin (Portugal). Hydrobiologia, 435: 167-175.

R DEVELOPMENT CORE TEAM. 2005. A Language and Environment for Statistical Computing. R Foundation for Statistical Computing, Vienna, Austria (url http://www.R-project.org).

RESH, V. H., M. J. MYERS \& M. J. HANNAFORD. 1996. Macroinvertebrates as biotic indicators of environmental quality. In: Methods in stream ecology. F. R. Hauer \& G. A. Lamberti (eds.): 647-665. Academic Press, San Diego, USA.

SOLÀ, C., M. BURGOS, A. PLAZUELO, J. TOJA, M. PLANS \& N. PRAT. 2004. Heavy metal bioaccumulation and macroinvertebrate community changes in a Mediterranean stream affected by acid mine drainage and an accidental spill (Guadiamar River, SW Spain). Science of The Total Environment, 333: 109-126.

STRIBLING, J. B., J. S. JESSUP, J. S. WHITE, D. BOWARD \& M. HURD. 1998. Development of a benthic index of biotic integrity for Maryland streams. Report, Tetra Tech Incorporated, Owings, Maryland, USA. pp. $38+$ Appendices.

TER BRAAK, C. J. F. \& P. SMILAUER. 1998. CANOCO Reference Manual and User's Guide to Canoco for Windows: Software for Canonical Community Ordination (version 4). Microcomputer Power, Ithaca, NY, USA.

VALENTE, A. C. N. 1990. As populações piscícolas do Rio Febros. $1^{\circ}$ Congresso Internacional sobre o rio Douro. Observatório, 1: 421-437.

VERSTEEG, D. J., S. E. BELANGER \& G. J. CARR. 1999. Understanding single-species and model ecosystem sensitivity: Data-based comparison. Environmental Toxicology and Chemistry, 18: 1329 1346. 